ISSN 1392-3196 / e-ISSN 2335-8947

Zemdirbyste-Agriculture, vol. 106, No. 2 (2019), p. 159-166

DOI 10.13080/z-a.2019.106.021

\title{
SSR analysis based on molecular characterisation of apple germplasm in Lithuania
}

\author{
Ingrida MAŽEIKIENE ${ }^{1}$, Jūratė Brone ŠIKŠNIANIENE ${ }^{1}$, Danas BANIULIS ${ }^{1}$, \\ Dalia GELVONAUSKIENE ${ }^{1}$, Birute FRERCKS ${ }^{1}$, Aurelijus STARKUS ${ }^{1}$, \\ Audronė ŽEBRAUSKIENË ${ }^{2}$, Vidmantas STANYS ${ }^{1,2}$ \\ ${ }^{1}$ Lithuanian Research Centre for Agriculture and Forestry, Institute of Horticulture \\ Kauno 30, Babtai, Kaunas distr., Lithuania \\ E-mail: i.mazeikiene@1sdi.lt \\ ${ }^{2}$ Vytautas Magnus University Agriculture Academy \\ Studentų 11, Akademija, Kaunas distr., Lithuania
}

\begin{abstract}
The survival of apple trees in old and abandoned orchards over 100 years indicates their adaptation to the local environment. These plants have passed an economic and ecological selection over the years. The structure of genetic diversity of apple germplasm in the old orchards of Lithuania is largely unknown. We applied a common set of 7 simple sequence repeat (SSR) markers to genotype 292 accessions across more than 50 geographic locations representing all Lithuanian geographic regions with the aim of analysing the distribution and structure of variation of the apple genetic resources. Eighty-one polymorphic alleles were identified. Of these, 5 alleles were unique, identified only in four individual genotypes. The COL locus was the most homozygous $(44.7 \%)$ among the cultivars and clones of the apple; however, the part of the germplasm may be heterozygous for nullalleles and those individuals cannot be distinguished from the homozygous ones. The CH02c11 locus was the most heterozygous $(90.0 \%)$ in the reference cultivars; meanwhile the $\mathrm{CH} 04 \mathrm{e} 05$ locus was the most heterozygous (84.4\%) among the analysed genotypes. Triploid genotypes constituted $12.5 \%$ among the analysed genotypes. A cluster analysis revealed 5 distinct clusters among the 182 diploid apple genotypes collected from the old orchards. According to molecular marker data, the names of 12 apple cultivars were attributed to 45 analysed unknown genotypes. It was found that traditional apple cultivars 'Popierinis', 'Paprastasis antaninis' and 'Pilkasis molinis' were the most prevalent cultivars in the old orchards. The apple genotypes that have survived in old orchards are valuable sources of traits for breeding as well as of high ecological, economic and heritage importance. Their use in breeding programs would significantly extend the diversity of adaptive genes of the domestic apple.
\end{abstract}

Key words: genetic resources of apple, identification of cultivar, Malus $\times$ domestica, microsatellite markers.

\section{Introduction}

Domestic apple (Malus $\times$ domestica Borkh.) is one of the most important fruit crops grown in temperate zones and occupies about 90 percent of the old orchards in Lithuania. It is not known when trees of $M . \times$ domestica were introduced to orchards in Lithuania. In the Second Statute of Lithuania, published in 1566, a punishment was established for destroying or theft of grafted trees. This shows that tree grafting and cultivation of fruit tree cultivars was common in Lithuania. By the $17^{\text {th }}$ century there were at least 120 cultivars described in Western Europe (Luby, 2003). Historically in the old Lithuanian homesteads of the $17^{\text {th }}-19^{\text {th }}$ centuries the gardens included landraces of local origin or cultivars originating from Western and Eastern Europe distributed through estates and monasteries. In the $20^{\text {th }}$ century, fruit trees were also imported from North America. A clonal selection of the most popular and commercially valuable cultivars has further contributed to the spread of the domestic apple trees in a certain region or throughout Lithuania for centuries. Until the first half of the $20^{\text {th }}$ century, orchards were planted with apple trees with a life cycle of up to 100 years. In this way, high-quality dessert fruit trees had withstood the economic and ecological test of time.

Although there are more than 10,000 documented apple cultivars worldwide (Hokanson et al., 2001), only a few well-adapted genotypes have been extensively used in apple breeding to release new cultivars with desirable traits in the last century (Laurens et al., 2010; Urrestarazu et al., 2016). The global apple production is dominated by relatively few cultivars, many of which are genetically closely related (Hokanson et al., 2001; Urrestarazu et al., 2016). The dramatic loss of genetic diversity in the

Please use the following format when citing the article:

Mažeikienė I., B. Šikšnianienė J., Baniulis D., Gelvonauskienė D., Frercks B., Starkus A., Žebrauskienė A., Stanys V. 2019. SSR analysis based on molecular characterisation of apple germplasm in Lithuania. Zemdirbyste-Agriculture, 106 (2): $159-166$. DOI 10.13080/z-a.2019.106.021 
orchards also hampers future plant breeding. The selected material of apple trees growing in the old orchards is unique for breeders in terms of genetic, ecological and economic heritage. Their use in breeding programs would significantly extend the crossing components. To protect the national cultural heritage, collections of old apple cultivars have been developed by several countries in Europe (Garkava-Gustavsson et al., 2008; van Treuren et al., 2010; Patzak et al., 2012; Urrestarazu et al., 2012; Bühlmann et al., 2015; Liang et al., 2015; Lassois et al., 2016). SSR markers have been used for assessment of genetic diversity among apple germplasm (Liebhard et al., 2002; Ramos-Cabrer et al., 2007) and cultivar genotyping (Garkava-Gustavsson et al., 2008; Sikorskaite et al., 2012). SSR loci are relatively easy to score, and alleles are inherited in a Mendelian manner, which allows the verification and reconstruction of cultivar pedigrees (Galli et al., 2005; Evans et al., 2011; Urrestarazu et al., 2016).

A previous study of diversity of the domestic apple germplasm in our country was performed using referenced old or commercial cultivars (Sikorskaite et al., 2012). In our research, we used microsatellite markers to genotype nearly three hundred apple accessions from old orchards in Lithuania. Specifically, our study was aimed to provide an insight into the genetic diversity that had been conserved at the level of the collection of genetic resources and nation-wide, and to explore usefulness of the microsatellite markers for identification of the local apple cultivars and landraces.

\section{Materials and methods}

Plant material. Plant material of domestic apple (Malus $\times$ domestica Borkh.) was collected from 292 apple trees from more than 50 old and abandoned orchard sites located in different geographical regions (Lazdijai, Utena, Molètai, Rokiškis, Panevėžys, Kaunas, Skuodas, Mažeikiai, Akmenė, Joniškis, Kelmè, Kèdainiai districts and Birštonas municipality) of Lithuania (Fig. 1). Based on the information collected from the owners, the sampled apple trees were more than 80 years old. Fifty traditional apple cultivars were used as a reference to identify the collected unknown genotypes.

DNA extraction. The apple genomic DNA was purified from $100 \mathrm{mg}$ of leaves, bark or buds using the CTAB (cetyl trimethylammonium bromide) method (Doyle, Doyle, 1990). DNA was dissolved in Tris-EDTA (TE) buffer (100 mM Tris-HCl, 10 mM EDTA, pH 8).

Simple sequence repeats (SSR) analysis. The primers for the SSR amplification were selected according to the European Cooperative Programme for Plant Genetic Resource (ECPGR) of Malus / Pyrus working group recommendations for apple trees: CH01h02, CH02c09, CH02c11, CH02d08, CH04c06, $\mathrm{CH} 04 \mathrm{e} 05$ and COL (Liebhard et al., 2002). The forward primer was labelled with fluorescent dye: 6-FAM, VIC, NED or PET (Applied Biosystems), primers for multiplex polymerase chain reaction (PCR) analysis was combined into three groups: A mix (CH01h02, $\mathrm{CH} 02 \mathrm{c} 09$ and $\mathrm{CH} 02 \mathrm{c} 1), \mathrm{B}$ mix $(\mathrm{CH} 02 \mathrm{~d} 08$ and $\mathrm{COL})$

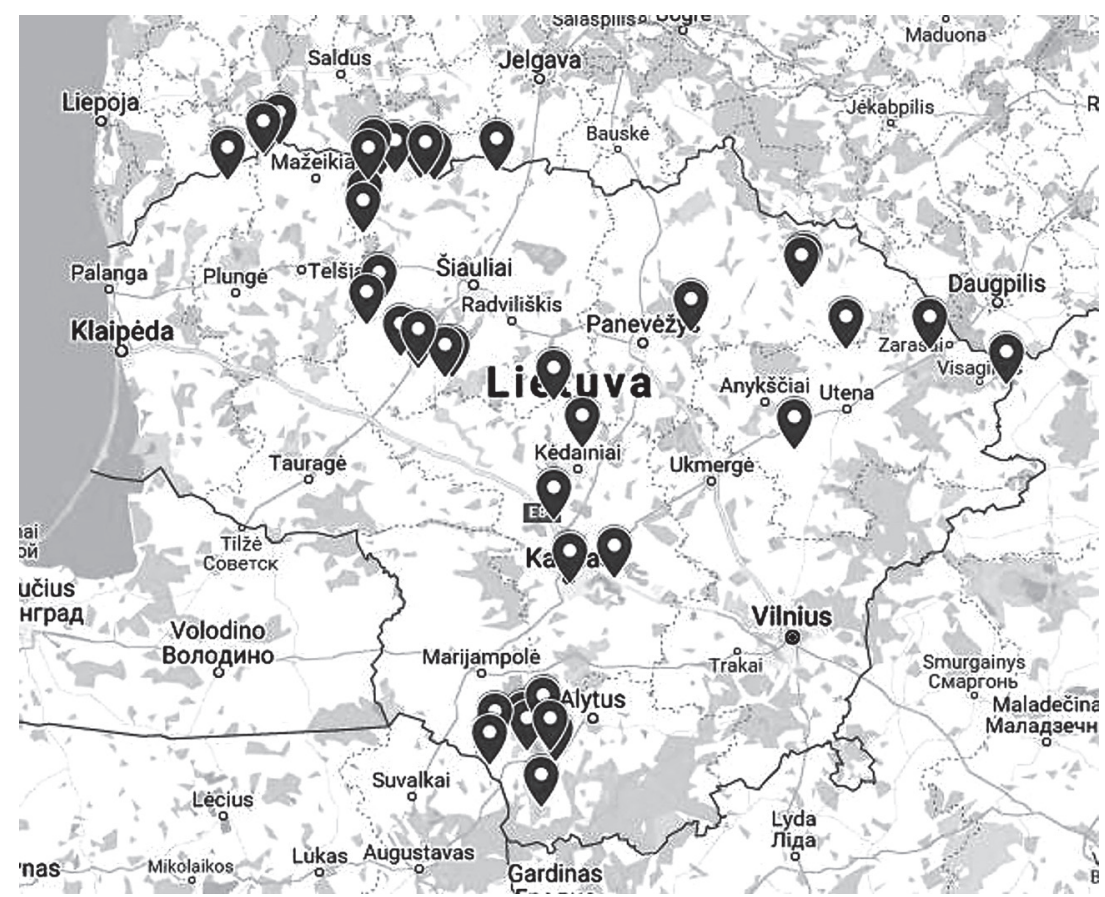

Figure 1. Geographic locations of the abandoned orchards of Malus $\times$ domestica studied in Lithuania

and $\mathrm{C}$ mix (CH04c06 and $\mathrm{CH} 04 \mathrm{e} 05)$. The PCR analysis was performed according to the method described by Horne et al. (2004). The reaction mixture (10 $\mu$ l volume) contained $60 \mathrm{ng}$ genomic DNA, 1\% PVP-30, $10 \mathrm{mM}$ DTT, $0.16 \mathrm{mM}$ dNTP, $1 \times$ PCR reaction buffer, $0.2 \mathrm{U}$ Taq DNA polymerase (Thermo Scientific), $0.5 \mathrm{mM}$ for each primer. Amplification of DNA fragments was performed in a thermocycler (Eppendorf): at $90 \mathrm{~s}$ at $95^{\circ} \mathrm{C} ; 10$ cycles with touchdown: $30 \mathrm{~s}$ at $94^{\circ} \mathrm{C}, 45 \mathrm{~s}$ at $60^{\circ} \mathrm{C}\left(0.5^{\circ} \mathrm{C}\right.$ in each cycle), $45^{\circ} \mathrm{C}$ at $72^{\circ} \mathrm{C} ; 25$ cycles: $30 \mathrm{~s}$ at $94^{\circ} \mathrm{C}, 45 \mathrm{~s}$ at $55^{\circ} \mathrm{C}, 45 \mathrm{~s}$ at $72^{\circ} \mathrm{C}$; the final fragment synthesis was carried out for $10 \mathrm{~min}$ at $72^{\circ} \mathrm{C}$. The analysis of PCR fragments was performed by the capillary electrophoresis using the 3130 Genetic Analyzer (Applied Biosystems).

Statistical analysis. SSR data was processed using software GeneMapper, version 4.0 (Applied Biosystems). The microsatellite fragments were evaluated using the program PowerMaker (Liu, Muse, 
2005). Hardy-Weinberg theory of equilibrium was used to calculate the frequency of null alleles. The null allele frequencies for each locus were estimated using Chakraborty et al. (1992) and Brookfield (1996) methods in software Micro-Checker, version 2.2.3 (Van Oosterhout et al., 2004). Unweighted neighbour-joining tree was constructed based on dissimilarities between the unique genotypes using the analysis methods (Perrier et al., 2003) provided in the software package DARwin, version 6.0.10 (Perrier, Jacquemoud-Collet, 2006).

\section{Results and discussion}

Microsatellite characterization. Eighty-one polymorphic alleles were identified for the reference and the old tree genotypes (Table 1). The number of alleles amplified with each pair of primers ranged from 9 to 16 , on average 11.6.
The value of expected heterozygosity directly reflects the genetic diversity - high value indicates a high level of genetic diversity. The value of observed heterozygosity reflects the degree of outcrossing. In this study, observed heterozygosity values ranged from 0.54 to 0.84 , on average 0.71 . The average observed heterozygosity value was similar to the heterozygosity characteristic of other apple populations described in previous studies. Garkava-Gustavsson et al. (2008) reported observed heterozygosity 0.74 in Swedish indigenous apple cultivars. Observed heterozygoty of 0.75 was estimated for the endangered wild apple Malus sylvestris population in Belgium (Coart et al., 2003). Expected heterozygosity value on average 0.76 of the apple germplasm analysed in this study was similar to those described by other authors in Danish population of European crab apple (Larsen et al., 2006), in Swedish population of indigenous apple cultivars (GarkavaGustavsson et al., 2008) and in unknown apple trees

Table 1. The variation of the investigated SSR loci observed in the study of apple germplasm

\begin{tabular}{cccccc}
\hline SSR primer & $\begin{array}{c}\text { Number } \\
\text { of allele }\end{array}$ & $\begin{array}{c}\text { Range } \\
\text { of allele, bp }\end{array}$ & $\begin{array}{c}\text { Observed } \\
\text { heterozygosity }\end{array}$ & $\begin{array}{c}\text { Expected } \\
\text { heterozygosity }\end{array}$ & PIC \\
\hline CH01h02 & 10 & $234-259$ & 0.63 & 0.64 & 0.60 \\
CH02c09 & 9 & $235-260$ & 0.81 & 0.81 & 0.79 \\
CH02c11 & 16 & $211-243$ & 0.84 & 0.85 & 0.83 \\
CH04c06 & 11 & $170-197$ & 0.71 & 0.73 & 0.71 \\
CH04e05 & 12 & $175-247$ & 0.71 & 0.72 & 0.68 \\
CH02d08 & 13 & $206-258$ & 0.73 & 0.83 & 0.81 \\
COL & 10 & $205-245$ & 0.54 & 0.74 & 0.71 \\
\hline Average & 11.6 & - & 0.71 & 0.76 & 0.73 \\
\hline
\end{tabular}

PIC - polymorphic information content

in North America (Gross et al., 2018), where the reported expected heterozygosity values on average were 0.78 , 0.74 and 0.75 , respectively. The polymorphic information content (PIC) varied from 0.60 to 0.83 , averaging 0.73 . All SSR primer pairs used in this study were very informative (PIC > 0.5) and suitable for identification of the reference and the old genotypes (Table 1).

The COL locus amplified mostly one SSR allele for the reference cultivars and the old tree genotypes of apple $-35.3 \%$ of the reference cultivars and $41.3 \%$ of the collected genotypes (Table 2), which may reflect homozygosity. However, it was found that null alleles were present in the COL locus in the population of analysed unknown apple genotypes and thus part of the individuals amplifying one allele may be heterozygous for null-allele. For this locus high homozygosity and possibility of presence of null alleles is typical, which was also observed in other studies (Ramos-Cabrer et al., 2007; Garkava-Gustavsson et al., 2008). The largest proportion of heterozygous genotypes was characteristic of the $\mathrm{CH} 02 \mathrm{c} 11$ locus $-92.2 \%$ among the reference cultivars and $79.0 \%$ among the old tree genotypes (Table 2).

Triploid accessions could be identified by presence of more than two alleles per locus in an apple genotype. Loci with three alleles were found in five apple cultivars 'Šafrano kinietè', 'Cinamoninis ananasas', 'Cinamono dryžètasis', 'Oleg' and 'Pupinis'. Among the reference cultivars, the largest proportion of possible triploid genotypes was $7.8 \%$ in the $\mathrm{CH} 04 \mathrm{c0} 0$ locus (Table 2). The SSR analysis of 281 unknown apple tree samples showed $12.5 \%$ of them to have loci with three

Table 2. The allele heterozygosity (\%) of the SSR loci among the reference apple cultivars and the old tree genotypes

\begin{tabular}{|c|c|c|c|c|c|c|}
\hline \multirow[b]{2}{*}{ SSR primer } & \multicolumn{2}{|c|}{ Homozygotes } & \multicolumn{2}{|c|}{ Heterozygotes } & \multicolumn{2}{|c|}{ Triploids } \\
\hline & $\begin{array}{l}\text { reference } \\
\text { cultivars }\end{array}$ & $\begin{array}{c}\text { analysed } \\
\text { genotypes }\end{array}$ & $\begin{array}{l}\text { reference } \\
\text { cultivars }\end{array}$ & $\begin{array}{c}\text { analysed } \\
\text { genotypes }\end{array}$ & $\begin{array}{l}\text { reference } \\
\text { cultivars }\end{array}$ & $\begin{array}{c}\text { analysed } \\
\text { genotypes }\end{array}$ \\
\hline CH01h02 & 31.4 & 37.0 & 66.7 & 62.3 & 2.0 & 0.7 \\
\hline $\mathrm{CH} 02 \mathrm{c} 09$ & 11.8 & 17.1 & 88.2 & 78.3 & 0.0 & 4.6 \\
\hline $\mathrm{CH} 02 \mathrm{c} 11$ & 7.8 & 14.2 & 92.2 & 79.0 & 0.0 & 6.8 \\
\hline $\mathrm{CH} 04 \mathrm{c} 06$ & 21.6 & 27.4 & 70.6 & 67.6 & 7.8 & 5.0 \\
\hline $\mathrm{CH} 04 \mathrm{e} 05$ & 21.6 & 32.7 & 76.5 & 65.9 & 2.0 & 1.4 \\
\hline $\mathrm{CH} 02 \mathrm{~d} 08$ & 23.5 & 23.8 & 76.5 & 74.1 & 0.0 & 2.1 \\
\hline $\mathrm{COL}$ & 35.3 & 41.3 & 62.7 & 53.4 & 2.0 & 5.3 \\
\hline
\end{tabular}


alleles. Some of the samples had the same SSR loci fingerprint. Therefore, 26 possible triploid genotypes were identified among the old apple trees. Unknown genotypes No. 15-64 and No. 15-83 belonged to cultivar 'Pupinis'. The largest proportion of putative triploids among analysed genotypes was identified in the locus CH02c11 (6.8\%), while the lowest proportion $(0.7 \%)$ was determined in the locus $\mathrm{CH} 01 \mathrm{~h} 02$ (Table 2). Loci CH02c09, $\mathrm{CH} 02 \mathrm{c} 11$ and $\mathrm{CH} 02 \mathrm{~d} 08$ did not amplify three alleles in any genotype. The frequency of triploids in a population from diploid parents had been investigated previously and the rate of $0.2-0.3 \%$ was described (Janick et al., 1996; Considine et al., 2012). More than $10 \%$ of triploid genotypes were found among economically valuable genotypes and cultivars of apple in different studies. Triploid genotypes constituted $10.9 \%$ of apple genetic resources in the study performed in Poland (Podwyszyńska et al., 2016), 21\% of triploid genotypes were identified in the Netherlands (van Treuren et al., 2010), and 28\% were found in Spain (Ramos-Cabrer et al., 2007).

Among the old apple tree genotypes, 81 polymorphic alleles were identified in seven loci (Fig. 2). According to the results obtained by the software PowerMaker, the frequency of alleles ranged from $0.2 \%$ to $54.5 \%$ in the investigated loci. Common alleles (frequency $p_{i}>10 \%$ ) were present in all investigated loci. The highest number (13) of rare alleles (frequency $p_{i} \leq 10 \%$ ) was amplified in loci $\mathrm{CH} 02 \mathrm{c} 11$. Similar results were obtained in the study of traditional Lithuanian apple cultivars (Sikorskaite et al., 2012). Five unique alleles were present only in the group of unknown apple population. Unique alleles were absent in the reference cultivars. Unique alleles were detected in loci $\mathrm{CH} 02 \mathrm{c} 09$ (245 bp), CH04c06 (188 bp), CH04e05 (191 and 196 bp) and COL (227 bp). Four unknown genotypes with unique alleles originated from different orchards in Lazdijai district and one genotype was from the homestead established in 1868 at Maldeikiškiai village in Rokiškis district. Among the reference cultivars and unknown genotypes, no unique alleles were detected in loci $\mathrm{CH} 01 \mathrm{~h} 02$, $\mathrm{CH} 02 \mathrm{~d} 08$ and $\mathrm{CH} 02 \mathrm{c} 11$. Group-specific alleles for Lithuanian population of apple have also been identified with high frequency in each locus. Interestingly, allele 239 in locus $\mathrm{CH} 01 \mathrm{~h} 02$ occurred with the highest frequency $(54.5 \%)$ in the Lithuanian population, while in native Swedish cultivars it was less frequent (17.6\%) (Garkava-Gustavsson et al., 2008), and in apple cultivars growing in Sarajevo or eastern Bosnia it was rare (3.9\%) (Gasi et al., 2013). The high frequency of some groupspecific alleles in the Lithuanian apple germplasm is likely to be inherited from Russian genepool with winter resistance, which led to the adaptation of plants in our geographic zone; similar results were observed in a genetic study of Finnish apple cultivars (GarkavaGustavsson et al., 2013).

Diversity of apple collection and identification of unknown genotypes. The dendrogram for the 250 diploid genotypes using the dataset of 7 SSR markers was constructed by ignoring the potential presence of null alleles (Fig. 3). The homozygosity was assumed when samples showed only a single allele for a microsatellite locus. As revealed by the analysis, a high genetic

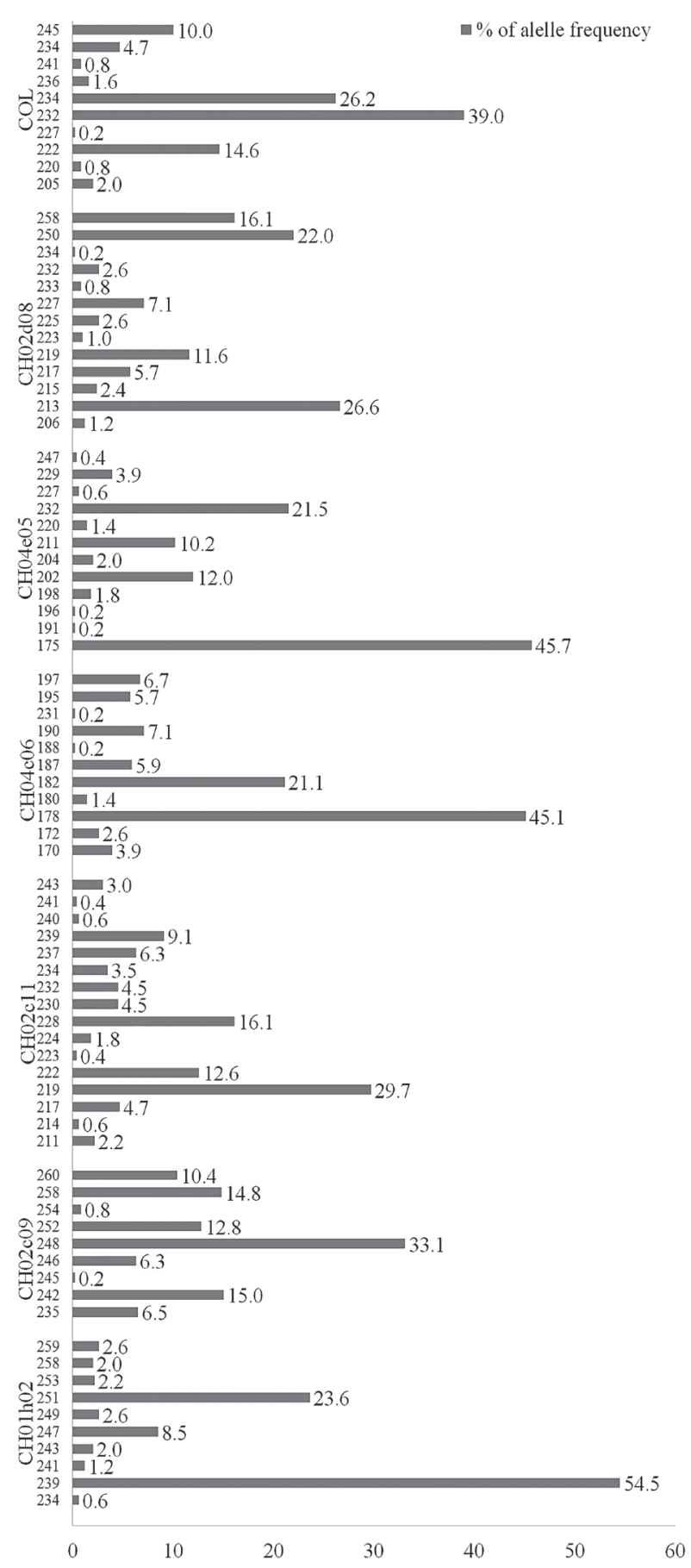

Figure 2. Allele sizes and frequencies (calculated by the software PowerMaker) of 7 SSR loci tested in 292 unknown tree apple genotypes from old and abandoned orchards in Lithuania

diversity among the apple trees collected from the old gardens in Lithuania was represented by 182 distinct genotypes. The genetic diversity of the heirloom apple cultivars and local genotypes has been evaluated by SSR in different regions of European countries (GarkavaGustavsson et al., 2008; Patzak et al., 2012; Urrestarazu et al., 2012; Garkava-Gustavsson et al., 2013; Liang et al., 2015; Lassois et al., 2016). The relationship among apple genepools and geographic-climatic zones through analysis of prevalence, variations and frequency of alleles were identified by the authors of these studies. The characteristic genepool of a country and distribution 


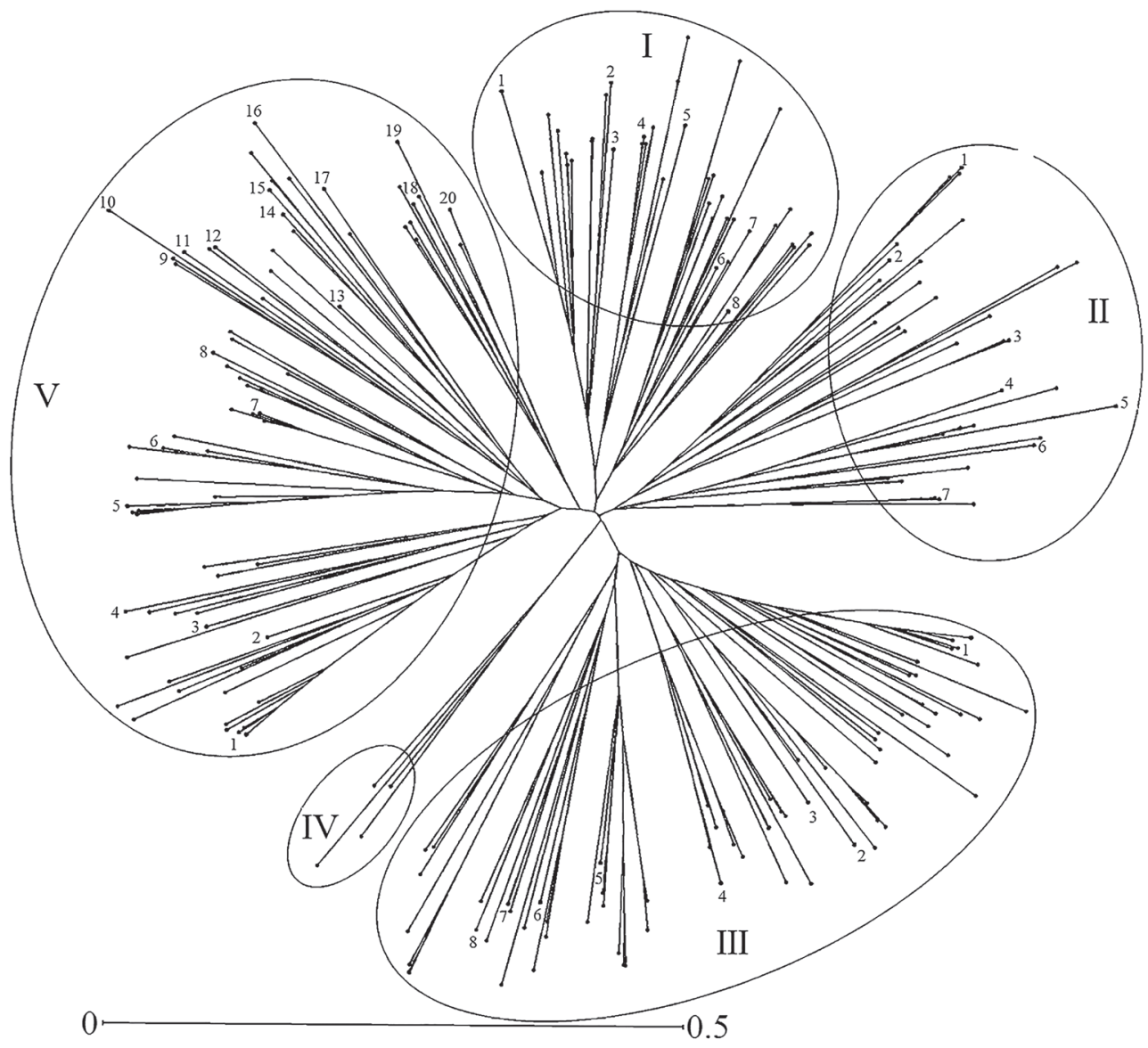

Note. Reference cultivars are indicated by numbers; cluster I: 1 - 'Popierinis', 2 - 'Aušris', 3 - 'Saldis', 4 - 'Pilkasis alyvinis', 5 - 'Panemunès baltasis', 6 - 'Korobovka', 7 - 'Biržuvėnų žieminis', 8 - 'Avenarijus'; cluster II: 1 - 'Lietuvos pepinas', 2 'Margutis', 3 - 'Signe Tillisch', 4 - 'Red Spy', 5 - 'Komsomolka', 6 - 'Puikis', 7 - Montvilinis'; cluster III: 1 - 'Paprastasis antaninis' ('Common Antonovka'), 2 - 'Persikinis', 3 - 'Streiflingas', 4 - 'Beforo kinietè, 5 - 'Geltonasis antaninis', 6 'Renette de Coulon', 7 - 'Lietuvos vinzorinis', 8 - 'Virginijos rožinis'; cluster IV: there are no reference cultivars in this cluster; cluster V: 1 - 'Pilkasis molinis', 2 - 'Vyninè', 3 - 'Babtų baltasis', 4 - 'Jono pepinas', 5 - 'Rudens dryžuotasis', 6 - 'Akeris', 7 - 'Suislepinis', 8 - 'Tabokinè', 9 - 'McIntosh', 10 - 'Discovery', 11 - 'Lobo', 12 - 'Melba', 13 - 'Snieginis', 14 - 'Žemaičiu grietininis', 15 - 'Worcester Pearmain', 16 - 'Vytis', 17 - 'Danų karalienė Luiza', 18 - 'Abrikosinis', 19 - 'Birutès pepinas', 20 - 'Lietuvos citrininis'.

Figure 3. Neighbour-joining dendrogram based on simple matching dissimilarity matrix calculated from the dataset of 7 SSR markers of 250 old apple tree genotypes and 42 reference cultivars

of a specific allele among landraces and local genotypes of apple was explained by the history of the introduction of cultivars, the geographic origin and the aspects of adaptability of plants to local climatic conditions. Urrestarazu et al. (2016) conducted a detailed study on the distribution of diversity of apple genus that classified the gene pool of European apple collections based on characteristic alleles into the three groups corresponding to the geographic location in North-East, West and South Europe. In our study, diploid apple reference cultivars and the old tree genotypes collected in Lithuanian gardens were clustered into five groups based on the allele distribution (Fig. 3).

The cluster analysis also revealed relationship of the old apple tree genotypes to the reference cultivars with different geographical origin. Cluster I include $19.2 \%$ of the old tree genotypes that were related to the reference cultivars originated from North-Eastern Europe. The reference cultivars introduced from North-
Western Europe and North America were grouped into the clusters II, III and V. 'Signe Tillisch' from Denmark and 'Red Spy' from the United States had common alleles with $15.4 \%$ of the old tree genotypes (cluster II). The old tree genotypes assigned to the cluster III (33.5\%) were genetically related to cultivars 'Paprastasis antaninis' ('Common Antonovka') (Kursk, Russia) and 'Renette de Coulon' (Belgium). Cluster V included 29.7\% of the old tree genotypes with alleles also characteristic of the reference cultivars from Canada ('McIntosh', 'Lobo' and 'Melba') and England ('Discovery' and 'Worcester Pearmain'). A small (2.2\%) genetically distinct group of genotypes was grouped in cluster IV. These old tree genotypes originated from three different orchards in Lazdijai district and had unique set of alleles that were not related to the reference genotypes. Therefore, the origin of these genotypes remains ambiguous. Based on the data from our study and findings of Urrestarazu and colleagues (2016), it could be summarized that 
the prevalent apple genotypes in the old orchards of Lithuania had characteristic alleles related to the apple gene pool common to the geographic regions of NorthEastern and Western Europe. The relationship of the old tree genotypes to the apple gene pool of Southern Europe remains unclear as the reference cultivars characteristic of Southern Europe were not used in our study.

The data in our study showed that the microsatellite profiles of apple genotypes from old and abandoned Lithuanian orchards and registered apple cultivars did not coincide in many cases. Analysis of the SSR profiles revealed that $45(15.4 \%)$ of the old tree genotypes had complete match with 12 reference cultivars: 'Korobovka' (1), 'Biržuvènu žieminis' (1), 'Pilkasis alyvinis' (1), 'Virginijos rožinis' (1), 'Signe Tillisch' (1), 'Lietuvos pepinas' (1), 'Red Spy' (3), 'Suislepinis' (3), 'Rudens dryžuotasis' (3), 'Popierinis' (8), 'Paprastasis antaninis' (12) and 'Pilkasis molinis' (13). As expected, the analysis confirmed that the old traditional cultivars 'Popierinis', 'Paprastasis antaninis' and 'Pilkasis molinis' were most prevalent in the old Lithuanian orchards included in the study. Identification of the remaining old tree genotypes would be complicated due to the lack of representative reference cultivars. Also part of the old apple trees could represent the hybrids that evolved through random selection from seedlings of extinct genotypes through folk breeding activity and the close genetic relationship with the current apple cultivars has been lost. The genotyping of apple gene pool was discussed by other authors (Garkava-Gustavsson et al., 2008; Gharghani et al., 2009; van Treuren et al., 2010; Gross et al., 2018). Molecular characterisation of indigenous Swedish apple cultivars based on SSR has been completed by Garkava-Gustavsson and colleagues (2008). The authors noted some discrepancies in allele sizes when comparing various previously published studies, which made it difficult to identify some apple genotypes without morphological evaluation. The accessions of Iranian cultivars and landraces of apple were assigned to six arbitrary populations by Gharghani et al. (2009), and results showed that all SSR loci displayed a very high degree of polymorphism. Van Treuren and colleagues (2010) concluded that microsatellite genotyping appeared a very efficient tool for enhancing collection management of genetic resources and for variety identification of apple, but discrepancies of data in this study were revealed and confirmed by the duplication analysis. Study of Gross et al. (2018) demonstrated the importance of local breeding programs, and also the challenges associated with identifying clones in such genetically diverse crop as apple.

Our study demonstrated that introduction of apple plant material from all over the world, suitable climate conditions for acclimation of plants and old tradition of breeding activities had expanded the gene pool of apple in the region. We collected and microsatellite genotyped a unique set of apple germplasm that would provide ample material for the future research on various aspects of apple genetic diversity and adaptability traits.

\section{Conclusions}

1. A highly divergent set of apple germplasm, including 182 diploid and 26 possible triploid genetically distinct genotypes, was collected from old orchards in Lithuania.

2. Five genetically distinct clusters of apple genotypes with distinct geographical origin were established according to the analysis of the allele diversity and the origin of the reference cultivars for the set of samples collected from the old orchards in Lithuania.

3 . Forty-five apple genotypes were identified by comparison with 12 reference apple cultivars: 'Paprastasis antaninis', 'Pilkasis molinis', 'Suislepinis', 'Rudens dryžuotasis', 'Korobovka', 'Biržuvènų žieminis', 'Pilkasis alyvinis', 'Popierinis' 'Signe Tillisch', 'Lietuvos pepinas', 'Red Spy' and 'Virginijos rožinis'. The apple cultivars 'Popierinis', 'Paprastasis antaninis' and 'Pilkasis molinis' were most prevalent in old Lithuanian orchards included in the study.

\section{Acknowledgements}

This work was carried out within the framework of the long-term research program "Genetics and direct genotype development of agricultural and forestry plants" implemented by the Lithuanian Research Centre for Agriculture and Forestry.

Received 15052018

Accepted 13022019

\section{References}

1. Brookfield J. F. Y. 1996. A simple new method for estimating null allele frequency from heterozygote deficiency. Molecular Ecology, 5 (3): 453-455. https://doi.org/10.1111/j.1365-294X.1996.tb00336.x

2. Bühlmann A., Gassmann J., Ingenfeld A., Hunziker K., Kellerhals M., Frey J. E. 2015. Molecular characterization of the Swiss fruit genetic resources. Erwerbs-Obstbau, 57 (1): 29-34. https://doi.org/10.1007/s10341-015-0230-1

3. Chakraborty R., De Andrade M., Daiger S. P., Budowle B. 1992. Apparent heterozygote deficiencies observed in DNA typing data and their implications in forensic applications. Annals of Human Genetics, 56: 45-47. https://doi.org/10.1111/j.1469-1809.1992.tb01128.x

4. Coart E., Vekemans X., Smulders M., Wagner I., Van Huylenbroeck J., Van Bockstaele E., Roldán-Ruiz I. 2003. Genetic variation in the endangered wild apple (Malus sylvestris (L.) Mill.) in Belgium as revealed by amplified fragment length polymorphism and microsatellite markers. Molecular Ecology, 12 (4): 845-857. https://doi.org/10.1046/j.1365-294X.2003.01778.x

5. Considine M. J., Wan Y., D'Antuono M. F., Zhou Q., Han M., Gao H., Wang M. 2012. Molecular genetic features of polyploidization and aneuploidization reveal unique patterns for genome duplication in diploid Malus. PLoS One, 7: e29449. https://doi.org/10.1371/journal.pone.0029449

6. Doyle J. J., Doyle J. L. 1990. Isolation of plant DNA from fresh tissue. Focus, 12 (1): 13-15.

7. Evans K. M., Patocchi A., Rezzonico F., Mathis F., Durel C. E., Fernández-Fernández F., Boudichevskaia A., Dunemann F., Stankiewicz-Kosyl M., Gianfranceschi L., Komjanc M., Lateur M., Madduri M., Noordijk Y., van de Weg W. E. 2011. Genotyping of pedigreed apple breeding 
material with a genome-covering set of SSRs: trueness-totype of cultivars and their parentages. Molecular Breeding, 28 (4): 535-547.

https://doi.org/10.1007/s11032-010-9502-5

8. Galli Z., Halász G., Kiss E., Heszky L., Dobránszki J. 2005. Molecular identification of commercial apple cultivars with microsatellite markers. Horticultural Science, 40 (7): 1974-1977. https://doi.org/10.21273/HORTSCI.40.7.1974

9. Garkava-Gustavsson L., Kolodinska Brantestam A., Sehic J., Nybom H. 2008. Molecular characterisation of indigenous Swedish apple cultivars based on SSR and S-allele analysis. Hereditas, 145 (3): 99-112. https://doi.org/10.1111/j.0018-0661.2008.02042.x

10. Garkava-Gustavsson L., Mujaju C., Sehic J., Zborowska A., Backes G. M., Hietaranta T., Antonius K. 2013. Genetic diversity in Swedish and Finnish heirloom apple cultivars revealed with SSR markers. Scientia Horticulturae, 162: 43-48. https://doi.org/10.1016/j.scienta.2013.07.040

11. Gasi F., Simon S., Pojskic N., Kurtovic M., Pejic I., Meland M., Kaiser C. 2013. Evaluation of apple (Malus $\times$ domestica) genetic resources in Bosnia and Herzegovina using microsatellite markers. Horticultural Science, 48 (1): 13-21. https://doi.org/10.21273/HORTSCI.48.1.13

12. Gharghani A., Zamani Z., Talaie A., Oraguzie N. C., Fatahi R., Hajnajari H., Wiedow C., Gardiner S. E. 2009. Genetic identity and relationships of Iranian apple (Malus $\times$ domestica Borkh.) cultivars and landraces, wild Malus species and representative old apple cultivars based on simple sequence repeat (SSR) marker analysis. Genetic Resources and Crop Evolution, 56 (6): 829-842. https://doi.org/10.1007/s10722-008-9404-0

13. Gross B. L., Wedger M. J., Martinez M., Volk G. M., Hale C. 2018. Identification of unknown apple (Malus $\times$ domestica) cultivars demonstrates the impact of local breeding program on cultivar diversity. Genetic Resources and Crop Evolution, 65 (5): 1317-1327. https://doi.org/10.1007/s10722-018-0625-6

14. Hokanson S. C., Lamboy W. F., Szewc-McFadden A. K., McFerson J. R. 2001. Microsatellite (SSR) variation in a collection of Malus (apple) species and hybrids. Euphytica, 118: 281-294. https://doi.org/10.1023/A:1017591202215

15. Horne E. C., Kumpatla S. P., Patterson K. A., Gupta M., Thompson S. A. 2004. Improved high-throughput sunflower and cotton genomic DNA extraction and PCR fidelity. Plant Molecular Biology Reporter, 22: 83-84. https://doi.org/10.1007/BF02773352

16. Janick J., Cummins J. N., Brown S. K., Hemmat M. 1996 Apples. Janick J., Moore J. N. (eds). Fruit breeding. I. Tree and tropical fruits. New York, USA, p. 1-77.

17. Larsen A., Asmussen C., Coart E., Olrik D., Kjær E. 2006. Hybridization and genetic variation in Danish populations of European crab apple (Malus sylvestris). Tree Genetics and Genomes, 2 (2): 86-97. https://doi.org/10.1007/s11295-005-0030-0

18. Lassois L., Denancé C., Ravon E., Guyader A., Guisnel R., Hibrand-Saint-Oyant L., Poncet C., LasserreZuber P., Feugey L., Durel C. E. 2016. Genetic diversity, population structure, parentage analysis and construction of core collections in the French apple germplasm based on SSR markers. Plant Molecular Biology Reporter, 34 (4): 827-844. https://doi.org/10.1007/s11105-015-0966-7

19. Laurens F., Durel C. E., Patocchi A., Peil A., Salvi S., Tartarini S., Velasco R., van de Weg W. E. 2010. Review on apple genetics and breeding programs and presentation of a new initiative of a news European initiative to increase fruit breeding efficiency. International Journal of Fruit Science, 27: $102-107$
20. Liang W., Dondini L., De Franceschi P., Paris R., Sansavini S., Tartarini S. 2015. Genetic diversity, population structure and construction of a core collection of apple cultivars from Italian germplasm. Plant Molecular Biology Reporter, 33: 458-473. https://doi.org/10.1007/s11105-014-0754-9

21. Liebhard R., Gianfranceschi L., Koller B., Ryder C. D., Tarchini R., Van De Weg E., Gessler C. 2002. Development and characterization of 140 new microsatellites in apple (Malus $\times$ domestica Borkh.). Molecular Breeding, 10 (4): 217-241.

https://doi.org/10.1023/A:1020525906332

22. Liu K., Muse S. V. 2005. PowerMaker: integrated analysis environment for genetic marker data. Bioinformatics, 21 (9): 2128-2129. https://doi.org/10.1093/bioinformatics/bti282

23. Luby J. J. 2003. The origin and spread of the domesticated apple. Ferree D. C., Warrington I. J. (eds). Apples: botany, production, and uses. CABI, p. 1-9.

24. Patzak J., Paprštein F., Henychová A., Sedlák J. 2012. Comparison of genetic diversity structure analyses of SSR molecular marker data within apple (Malus $\times$ domestica) genetic resources. Genome, 55: 647-665. https://doi.org/10.1139/g2012-054

25. Perrier X., Jacquemoud-Collet J.-P. 2006. DARwin software. http://darwin.cirad.fr/darwin

26. Perrier X., Flori A., Bonnot F. 2003. Data analysis methods. Hamon P. et al. (eds). Genetic diversity of cultivated tropical plants, p. 43-76.

27. Podwyszyńska M., Kruczyńska D., Machlańska A., Dyki B., Sowik I. 2016. Nuclear DNA content and ploidy level of apple cultivars including Polish ones in relation to some morphological traits. Acta Biologica Cracoviensia, Series Botanica, 58 (1): 81-93. https://doi.org/10.1515/abcsb-2016-0008

28. Ramos-Cabrer A. M., Díaz-Hernández M. B., PereiraLorenzo S. 2007. Morphology and microsatellites in Spanish apple collections. Journal of Horticultural Science and Biotechnology, 82 (2): 257-265. https://doi.org/10.1080/14620316.2007.11512227

29. Sikorskaite S., Gelvonauskiene D., Stanys V., Baniulis D. 2012. Characterization of microsatellite loci in apple (Malus $\times$ domestica Borkh.) cultivars. ZemdirbysteAgriculture, 99 (2): 131-138.

30. Urrestarazu J., Miranda C., Santesteban L. G., Royo J. B. 2012. Genetic diversity and structure of local apple cultivars from Northeastern Spain assessed by microsatellite markers. Tree Genetics and Genomes, 8: 1163-1180. https://doi.org/10.1007/s11295-012-0502-y

31. Urrestarazu J., Denancé C., Ravon E. et al. 2016. Analysis of the genetic diversity and structure across a wide range of germplasm reveals prominent gene flow in apple at the European level. BMC Plant Biology, 16: 130. https://doi.org/10.1186/s12870-016-0818-0

32. Van Oosterhout C., Hutchinson W. F., Wills D. P. M., Shipley P. 2004. Micro-checker: software for identifying and correcting genotyping errors in microsatellite data. Molecular Ecology Notes, 4 (3): 535-538. https://doi.org/10.1111/j.1471-8286.2004.00684.x

33. van Treuren R., Kemp H., Ernsting G., Jongejans B., Houtman H., Visser L. 2010. Microsatellite genotyping of apple (Malus $\times$ domestica Borkh.) genetic resources in the Netherlands: application in collection management and variety identification. Genetic Resources and Crop Evolution, 57 (6): 853-865. https://doi.org/10.1007/s10722-009-9525-0 
ISSN 1392-3196 / e-ISSN 2335-8947

Zemdirbyste-Agriculture, vol. 106, No. 2 (2019), p. 159-166

DOI 10.13080/z-a.2019.106.021

\title{
Lietuvoje paplitusių obels genotipų molekulinis apibūdinimas taikant paprastos pasikartojančios sekos analizès metodą
}

\author{
I. Mažeikienè ${ }^{1}$, J. B. Šikšnianienè ${ }^{1}$, D. Baniulis ${ }^{1}$, D. Gelvonauskienè ${ }^{1}$, B. Frercks ${ }^{1}$, A. Starkus ${ }^{1}$,
} A. Žebrauskiené2, V. Stanys ${ }^{1,2}$

${ }^{1}$ Lietuvos agrarinių ir miškų mokslų centro Sodininkystès ir daržininkystès institutas

${ }^{2}$ Vytauto Didžiojo universiteto Žemès ūkio akademija

\section{Santrauka}

Obelų vaismedžių išgyvenimas 100 ir daugiau metų rodo jų prisitaikymą prie vietos biotinių ir abiotinių veiksnių visumos. Tik ūkiškai vertingos veislès ilgą laiką plito tam tikrame regione arba visoje Lietuvoje. Šie augalai yra išlikę po ilgalaikès ekonominès ir ekologinės atrankos. Senų ir apleistų Lietuvos obelų sodų genetinės ịvairovės struktūra yra nežinoma. Siekiant išanalizuoti naminès obels genetinių išteklių variacijos pasiskirstymą ir struktūrą, tyrimo metu panaudojus 7 paprastos pasikartojančios sekos (PPS) žymeklius, identifikuoti 292 genotipai, surinkti iš daugiau nei 50 geografinių vietovių, būdingų visiems šalies geografiniams regionams. Tirtuose obels genotipuose identifikuotas 81 polimorfinis alelis. Iš jų 5 aleliai yra unikalūs, nustatyti keturiuose atskiruose genotipuose. Obels veislès ir genotipai dažniausiai buvo homozigotiniai COL lokuse $(44,7$ \%). Žinomos heterozigotinės obels veislès dažniausiai buvo CH02c11 lokuse (90,0 \%), o nežinomi obels genotipai - CH04e05 lokuse $(84,4$ \%). Tarp nežinomų obels genotipų nustatyta 12,5 \% triploidų. Panaudojus žymeklių duomenis, 45 genotipams buvo priskirti 12 žinomų veislių pavadinimai. Nustatyta, kad senuose soduose labiausiai paplitusios yra obelų veislès 'Popierinis', 'Paprastasis antaninis', 'Lietuvos pepinas' ir 'Pilkasis molinis'.

Senuosiuose soduose augančių obelų genotipai yra unikalūs selekciniu, ekologiniu, ekonominiu ir paveldosauginiu atžvilgiu. Jų panaudojimas obels selekcinėse programose reikšmingai praplèstų adaptyvumo genų įvairovę.

Reikšminiai žodžiai: identifikuotos veislès, Malus $\times$ domestica, mikrosatelitų žymekliai, obelų genų ištekliai. 